\title{
Correction to: How to specify healthcare process improvements collaboratively using rapid, remote consensus-building: a frame work and a case study of its application
}

Jan W. van der Scheer ${ }^{1 *}$, Matthew Woodward ${ }^{1}$, Akbar Ansari $^{1}$, Tim Draycott ${ }^{2,3}$, Cathy Winter ${ }^{3}$, Graham Martin ${ }^{1}$, Karolina Kuberska ${ }^{1}$, Natalie Richards ${ }^{1}$, Ruth Kern ${ }^{1}$ and Mary Dixon-Woods ${ }^{1}$ Thiscovery Authorship Group, Obstetric Emergency Consensus Authorship Group

Correction to: BMC Med Res Methodol 21, 103 (2021) https://doi.org/10.1186/s12874-021-01288-9

Following publication of the original article [1], the author noticed that:

1) Two names are missing from the acknowledgements section under "Obstetric Emergency Consensus Authorship Group" ("Rachel Corry" and "Celine McKeown"). The list in that section should read:

Amanda Andrews, Rita Arya, Sarah F. Bell, Denise Chaffer, Andrew Cooney, Rachel Corry, Mair G.P. Davies, Lisa Duffy, Caroline Everden, Theresa Fitzpatrick, Courtney Grant, Mark Hellaby, Tracey A. Herlihey, Sue Hignett, Sarah Hookes, Fran R. Ives, Gyuchan T. Jun, Owen J. Marsh, Tanya R. Matthews, Celine McKeown, Alexandra Merriman, Giulia Miles, Susan Millward, Neil Muchatata, David Newton, Valerie G. Noble, Pamela Page, Vincent Pargade, Sharon P. Pickering, Laura Pickup, Dale Richards, Cerys Scarr, Jyoti Sidhu, James Stevenson, Ben Tip-

The original article can be found online at https://doi.org/10.1186/s12874021-01288-9.

\footnotetext{
${ }^{*}$ Correspondence: jan.vanderscheer@thisinstitute.cam.ac.uk
}

${ }^{1}$ THIS Institute (The Healthcare Improvement Studies Institute),

Departmentof Public Health and Primary Care, University of Cambridge,

Cambridge Biomedical Campus, Clifford Allbutt Building, Cambridge CB2

$\mathrm{OAH}$, UK

Full list of author information is available at the end of the article ney, Stephen Tipper, Jo Wailling, Susan P. WhalleyLloyd, Christian Wilhelm, Juliet J. Wood.

2) These two names ("Rachel Corry", "Celine McKeown") are also missing from the Authorship Group name and the tagging of them in databases such as Pubmed. The two names need to be added accordingly as well.

The original article has been corrected.

\begin{abstract}
Author details
${ }^{1}$ THIS Institute (The Healthcare Improvement Studies Institute), Departmentof Public Health and Primary Care, University of Cambridge, Cambridge Biomedical Campus, Clifford Allbutt Building, Cambridge CB2 OAH, UK. ${ }^{2}$ Department of Translational Health Services, University of Bristol, Bristol, UK. ${ }^{3}$ PROMPT Maternity Foundation, Women and Children's Health, North Bristol NHS Trust, Westbury on Trym, UK.
\end{abstract}

Published online: 29 July 2021

Reference

1. van der Scheer JW, Woodward M, Ansari A, et al. How to specify healthcare process improvements collaboratively using rapid, remote consensus-building: a framework and a case study of its application. BMC Med Res Methodol. 2021;21:103. https://doi.org/10.1186/s12874-021-01288-9.

\section{Publisher's Note}

Springer Nature remains neutral with regard to jurisdictional claims in published maps and institutional affiliations.

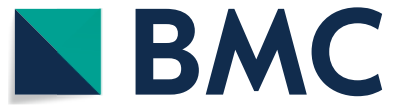

(c) The Author(s) 2021. Open Access This article is licensed under a Creative Commons Attribution 4.0 International License, which permits use, sharing, adaptation, distribution and reproduction in any medium or format, as long as you give appropriate credit to the original author(s) and the source, provide a link to the Creative Commons licence, and indicate if changes were made. The images or other third party material in this article are included in the article's Creative Commons licence, unless indicated otherwise in a credit line to the material. If material is not included in the article's Creative Commons licence and your intended use is not permitted by statutory regulation or exceeds the permitted use, you will need to obtain permission directly from the copyright holder. To view a copy of this licence, visit http://creativecommons.org/licenses/by/4.0/. The Creative Commons Public Domain Dedication waiver (http://creativeco mmons.org/publicdomain/zero/1.0/) applies to the data made available in this article, unless otherwise stated in a credit line to the data. 